\title{
DIETARY HABITS AMONG YOUNG TRIATHLONISTS AS A RESULT OF PROECOLOGICAL STYLE OF LIFE - PRELIMINARY STUDY
}

\author{
Zbigniew Szygula1 $^{(\mathrm{A}, \mathrm{D}, \mathrm{E})}$, Karolina Kazimierczak $^{2(\mathrm{~B}, \mathrm{D})}$, Edward Golec ${ }^{3(\mathrm{D}, \mathrm{E})}$, Malgorzata Schlegel-Zawadzka $^{2(\mathrm{~A}, \mathrm{C}, \mathrm{D}, \mathrm{E}, \mathrm{F}, \mathrm{G})}$ \\ ${ }^{1}$ Department of Sports Medicine, University School of Physical Education, Kraków, Poland \\ ${ }^{2}$ Department of Human Nutrition, Institute of Public Health, Faculty of Health Sciences, Jagiellonian \\ University Medical College, Kraków, Poland \\ ${ }^{3}$ Faculty of Physiotherapy, University School of Physical Education, Kraków, Independent Public Health Care \\ Centre, $5^{\text {th }}$ Military Clinical Hospital with Policlinic, Department of Traumatic Surgery and Orthopaedics, \\ Kraków, Poland
}

\begin{abstract}
Introduction: Strenuous physical activity during the preparatory training period calls for an extra dose of a care necessary for the young athlete to perform well. In accord with proper exercise training, an adequate nutrition diet plays an equally important role in maintaining the athlete's healthy physical condition.

The aim of this study was to recognize dietary habits among young triathlonists.

Material and methods: Nine triathlonists, aged $15-18$ years ( 6 boys and 3 girls), and 9 non-training youth in the same sex and age group category, participated in the study. The data was collected by administering a questionnaire.

Results: The results collected in this study showed that triathlonists lead a more ecological lifestyle in comparison with the population not engaged in triathlon training. The triathlonists tended to consume a more balanced diet.

Conclusion: Promoting triathlon as pro-ecological discipline may aid in raising social awareness of maintaining proper physical activity and nutrition diet in the population.
\end{abstract}

Keywords: youth, triathlon, ecological sport, dietary habits

\section{Introduction}

Strenuous physical activity during the (preparatory) training period raises an issue of attention that is being paid to the young athlete's body. The literature published thus far, has mainly focused on specific exercise sports, such as swimming, cycling, and running that influence an athlete's overall health and physical performance. However, not only does the exercise training influence the physical condition and health of an athlete, but a proper, balanced diet plays an equally important role in the athlete's performance.

During preparation of his or her training plan, an athlete, in cooperation with his or her personal coach and a physician, needs to design an adequate diet that would consist of supplements and nutrients.

A triathlon is an olympic, athletics competition which combines three disciplines - swimming, cycling, and running. Athletes need to be properly prepared for all three events. At the present time, a limited body of scientific literature focuses on this issue, and virtually no studies on Polish triathlonists have been carried thus far.

Therefore, an aim of this study was to recognize dietary habits among young Polish triathlonists.

\section{Subject and methods}

The study was conducted in the northern Poland from period of September to March, 2007 in a group of 34 triathlonists (Athletes - A) and 34 non-athletes (Control - C). This number accounts approximately for the L' of all Polish triathlonists. Both groups were similar concerning subjects aged (15-25 years) and the same sex. This was a questionnaire case control study. This researh paper presents results from a study of 9 triathlonists, aged $15-18$ years $(17.11 \pm 1.17$ years; 6 boys and 3 girls), and 9 non-training youths in the same sex and age group. Questionnaire comprised of questions pertaining to the triathlonists' life style and their dietary habits. Dietary intake of select food products and supplements was evaluated.

Several scales were used: two points for existence of phenomenon (1- no, 2- yes), four points for drinking (1-never; 2- occasionally; 3-1-2 glasses; 4- 3-5 glasses), six points for food products intake (1- never; 2 -less than once a week; 3 - once a week; 4- several times a week; 5- once a day; 6- more than once a day).

Data was evaluated with the Microsoft Excel 2003 and statistical software Statistica Pl 8.0 (StatSoft firm). Results were presented as arithmetic mean \pm standard 
deviation. The differences between tested groups were assessed by non-parametric test - Manna-Whitney. The R Spearman correlation coefficient was a tool of similarity evaluation of food frequency intake in A and $\mathrm{C}$ groups. The level of significant differences was alpha $=0.05$.

\section{Results}

The data collected during this study allowed the authors to conclude that triathlonists lead a more ecological life style in comparison with the population who does not engage in triathlon training. The athletes tended to eat a more balanced diet, which might be a result of a nutritional, athlete's coach, and a physician counseling.

In order to improve their performance, thriathlonists consume a variety of nutritional supplements. Triathlonists showed a tendency to most frequently ingest energizers (89\%), substance building nutriments (52\%), multivitamin-minerals supplements (78\%), and isotonic liquids (67\%).

The subjects in the study tended to show different reasons for engaging in physical activity: among athletes, this group maintained a physical activity (67\%) and remained healthy and fit ( $44 \%$ each), while non- athletes showed a physical fitness (67\%) and health level (27\%) (Tab. 1).

The majority of the subjects consumed four meals (50\%) and five meals (28\%) during the day. 33\% of athletes declared to have a special diet.

The most commonly consumed beverage/fluid among athletes was mineral water $(3.89 \pm 0.33)$. The athletes consumed significantly higher doses of fluids in comparison with the non-athletes $(3.33 \pm 0.50$; $P=0.0188$ ). Intake of gaseous beverages was also diagnosed in both groups. According to collected data, subjects in group $\mathrm{C}$ drank much more gaseous beverages than those in group A $(P=0.0156)$. Other beverages, such as coffee, tea, herbal tea, fruit juices, milk, energizers, and beer, were consumed in the similar manner in both groups (Tab. 2).

The consumption of 27 types of food products was examined (Tab. 3). The comparison of food frequency intake by both groups was calculated. The significant differences were found in fruits, sweets and chips consumption. Thriatlonists ate fruits more frequently (A: $5.44 \pm 0.73, \mathrm{C}: 3.67 \pm 1.12, P=0.0035)$ and less frequently sweets (A: $3.22 \pm 1.20, \mathrm{C}: 4.67 \pm 1.66, P=0.0393$ ) as well as potato chips (A: $1.67 \pm 0.71,3.78 \pm 1.66, P=0.0076$ ). The calculated R Spearman correlation coefficient

Table 1. Cause of physical effort. (Scale: 1- no, 2- yes)

\begin{tabular}{|c|c|c|}
\hline \multirow{3}{*}{ Parameter } & Triathlonists & Non-triathlonists \\
$\mathrm{N}=9$ & $\mathrm{~N}=9$ \\
& $\mathrm{X} \pm \mathrm{SD}$ & $\mathrm{X} \pm \mathrm{SD}$ \\
\hline Condition & $1.67+0.50$ & $1.67+0.50$ \\
\hline Health & $1.44+0.53$ & $1.22+0.44$ \\
\hline Silhouette & $1.44+0.53$ & $1.67+0.50$ \\
\hline Professionally & $1.33+0.50$ & 0 \\
\hline
\end{tabular}

$\mathrm{N}$-number of persons, $\mathrm{X} \pm \mathrm{SD}$ - arithmetic mean \pm standard deviation

Table 2. Number and frequency of drinking liquids daily by study groups (Scale: 1-never; 2- occasionally; 3- 1-2 glasses; 4-3-5 glasses)

\begin{tabular}{|c|c|c|}
\hline Parameter & $\begin{array}{l}\text { Triathlonists } \\
\qquad \begin{array}{c}\mathrm{N}=9 \\
\mathrm{X} \pm \mathrm{SD}\end{array}\end{array}$ & $\begin{array}{l}\text { Non-triathlonists } \\
\qquad \begin{array}{c}\mathrm{N}=9 \\
\mathrm{X} \pm \mathrm{SD}\end{array}\end{array}$ \\
\hline Coffee & $1.78+0.67$ & $1.56+0.73$ \\
\hline Tea & $2.78+0.67$ & $3.11+0.60$ \\
\hline Mineral water $\mathrm{p}=0.0188$ & $3.89+0.33$ & $3.33+0.50$ \\
\hline Gaseous beverages $\mathrm{p}=0.0156$ & $2.11+0.93$ & $3.33+0.87$ \\
\hline Herbal tea & $1.89+0.78$ & $1.56+0.73$ \\
\hline Fruit juices & $2.56+0.88$ & $3.00+0.71$ \\
\hline Milk & $2.78+0.67$ & $2.89+0.93$ \\
\hline Energitizers & $1.67+0.50$ & $1.56+0.53$ \\
\hline Beer & $1.67+0.50$ & $1.67+0.71$ \\
\hline
\end{tabular}

$\mathrm{N}$-number of persons, $\mathrm{X} \pm \mathrm{SD}$ - arithmetic mean+standard deviation 
Table 3. Frequency intake of selected food products. Scale: 1- never; 2-less than once a week; 3- once a week; 4- several times a week; 5- once a day; 6- more than once a day)

\begin{tabular}{|c|c|c|}
\hline Parametr & $\begin{array}{l}\text { Triathlonists } \\
\qquad \begin{array}{c}\mathrm{N}=9 \\
\mathrm{X} \pm \mathrm{SD}\end{array}\end{array}$ & $\begin{array}{c}\text { Non-triathlonists } \\
\qquad \mathrm{N}=9 \\
\mathrm{X} \pm \mathrm{SD}\end{array}$ \\
\hline Rolls and white bread & $4.67+2.18$ & $5.56+1.01$ \\
\hline Dark bread & $3.56+1.33$ & $3.44+1.81$ \\
\hline Pasta and noodles & $3.56+1.01$ & $3.44+0.88$ \\
\hline Muesli & $4.44+0.73$ & $3.78+1.09$ \\
\hline Grits, rice & $3.44+0.73$ & $3.11+0.78$ \\
\hline Fat milk & $3.44+1,51$ & $3.44+1.24$ \\
\hline Skimmed milk & $3.00+1.41$ & $2.89+1.96$ \\
\hline Yoghurt, kefir & $4.22+1.39$ & $3.67+0.87$ \\
\hline Cottage cheeses & $3.89+1.05$ & $3.11+0.93$ \\
\hline Hard cheeses (yellow) & $4.22+1.56$ & $4.78+0.83$ \\
\hline Beef and pork & $3.56+0.73$ & $3.22+1.09$ \\
\hline Non-fat sausages & $3.11+1.05$ & $3.33+1.58$ \\
\hline Fat sausages and offal & $3.11+1.05$ & $3.78+0.67$ \\
\hline Poultry & $3.78+0.97$ & $3.78+1.30$ \\
\hline Fishes & $3.33+1.00$ & $2.56+1.42$ \\
\hline Butter & $3.67+2.55$ & $4.78+1.72$ \\
\hline Margarine, flora & $3.33+2.18$ & $3.44+2.01$ \\
\hline Potatoes & $3.89+1.62$ & $4.56+0.73$ \\
\hline Vegetable and fruit Salado & $4.78+1.20$ & $4.00+1.00$ \\
\hline Fruits $(\mathrm{p}=0.0035)$ & $5.44+0.73$ & $3.67+1.12$ \\
\hline Fruit juices & $4.00+1.32$ & $3.67+1,22$ \\
\hline Dry seeds of leguminous & $2.22+1.64$ & $2.33+1.66$ \\
\hline Sugar & $3.78+2.11$ & $4.44+1.33$ \\
\hline Sweets $(\mathrm{p}=0.0393)$ & $3.22+1.20$ & $4.67+1.66$ \\
\hline Chips $(\mathrm{p}=0.0076)$ & $1.67+0.71$ & $3.78+1.66$ \\
\hline Cakes & $2.67+1.12$ & $4.00+1.50$ \\
\hline Ice creams & $2.67+1.50$ & $3.00+1.41$ \\
\hline \multicolumn{3}{|c|}{ Correlation coefficient } \\
\hline
\end{tabular}

$\mathrm{N}$-number of persons, $\mathrm{X}+\mathrm{SD}$ - arithmetic mean+standard deviation

comparing similarity of frequency consumption of 27 food products in each group was statistically insignificant (R. Spearman $=0.29, P>0.05)$. This means that in total, the selected products were consumed in different amounts in both groups.

\section{Discussion}

Ecological training is the main postulate of triathlon as a sports discipline (clean forests, lakes, and rivers). Strain during the preparatory training enforces extra care of athletes' body - especially one's joints in legs. The overall environment, ie., the ground on which triathlonists run, the water they swim in, and the air they breathe in, are all very important for maintaining a good health. Air pollution can negatively affect the athlete's health, which furthermore may play a role in their sports performance.

Thus far, the conducted study only examined the influence of each singular triathlon sports discipline on the total result that sportsman gains in the triathlon participation (1). They checked the dehydration during the longest triathlon distance which is "Ironman", but none of them evaluated the way of sportsmen nourishment during triathlon.

Aside from designing a proper training plan, an athlete, in cooperation with his or her coach and his or her physician, should focus on an adequate diet $(2,3)$.

The evidence collected during the study allowed the authors to state that triathlonists lead more ecological 
mode of life than the people that do not train triathlon. The diet evaluated in sportsmen, tended to be more balanced, which might be the effect of a consultations with the coach, physician and nutritionist. In order to improve their performance during training and competition, thriathlonists intake various types of nutriments and supplements.

Beneficial results were also noted after comparing the fluid intake during the day in both groups. Mineral water was a most frequently used drink among triathlonists. This may be the result of the athletes' awareness of the value of proper hydration during the day (4-7). The results gained on researchers own investigation material lead to beneficial results - triathlonists tented to point to fruits and vegetables as the most frequently ingested by them products. Additionally, cereal and milk products, fat meat products, and sweets placed on the lowest position.

A variety of elements play into one's lifestyle. One of the most commonly used elements we can enumerate way of nutrition, way of coping with stress, relationship building at work, or relaxing.

The topic of nutrition poses a serious concern in Poland. The study shows a strong link between the poor nutrition and poor quality of lifestyle in Poland.

A study conducted by Wlodarczyk shows that $86 \%$ of Polish population does not recognize the relationship between their health problems and attention one pays to his or her health (8).

Physical activity plays a very important role in health promotion. This study also shows that trathlonists lead a more healthy lifestyle than individuals not engaged in exercise training.

A strong connection between frame of mind, proper psychophysical development and the life-style one exists. Unhealthy nutrition and low value food intake are one of the most common reasons of serious disorders and diseases. Adequate and rational nutritional diet promotes good health and helps to prevent various disorders, such as obesity, hypertension, caries, and large intestine cancer.

Since no earlier scientific literature and data regarding this type of study exists, more research on this topic is necessary to confirm the importance of our research study results.

The above study shows that promoting triathlon as pro-ecological discipline may aid in raising social awareness of nutrition value and physical activity in free time.

\section{Conclusions}

Promoting triathlon as pro-ecological discipline may aid in raising social awareness of maintaining proper physical activity and nutrition diet in the population. It is important to educate coaches specializing in various sport disciplines about the importance of proper nutrition diet in young athletes since these educators will be able to raise this awareness in their athletes.

\section{Acknowledgement}

We are very grateful to Ms. Danuta Charland for correcting the English grammar and style of the final version of the manuscript.

\section{References}

1. De Vito G, Bernardi M, Sproviero E, Figura F. Decrease of endurance performance during Olympic triathlon. Int $J$ Sports Med 1995; 16(11): 24-8.

2. Davies C, Thompson M. Physiological responses to prolonged exercise in ultramarathon athletes. J Appl Physiol 1986; 61(2): 611-7.

3. Raczyńska B, Raczyński G. Sport i żywienie. Warszawa Centralny Ośrodek Sportu, Resortowe Centrum Metodyczno-Szkoleniowe Kultury Fizycznej i Sportu, 1996.

4. Szygula Z. Choroba cieplna u sportowców i sposoby jej zapobiegania. (cz. I). Sport Wyczynowy 1997; 35 (7-8): 60-9 (in Polish, Abstract in English).

5. Noakes T. Lore of running. Fourth edition. Cape Town: Oxford University Press, 2001.

6. Szygula Z. Choroba cieplna u sportowców i sposoby jej zapobiegania. (cz. II). Sport Wyczynowy 1997: 35 (9-10): 54-63 (in Polish, Abstract in English).

7. Frizzera S, Bertoli P, Resnyak S, Wiedmann K. Triathlon: Herkömmliche und neue Aspekte in der Funktionsdiagnostik. Dtsch Z Sportmed 1991; 8: 18.

8. Włodarczyk P. Edukacyjne uwarunkowania zachowań zdrowotnych studentów. Warszawa: Wydawnictwo AWF, 2002.

9. Podolec P. Podręcznik Polskiego Forum Profilaktyki, T. 1. Kraków: Medycyna Praktyczna, 2007.

Received: June 03, 2009

Accepted: September 02, 2009

Published: September 04, 2009

Address for correspondence:

Zbigniew Szygula

University School of Physical Education

P.O. Box 62

31-571 Krakow

Poland

Tel. +48126831223

email: wfszygula@cyf-kr.edu.pl

Edward Golec: bgolec@poczta.onet.pl

Małgorzata Schlegel-Zawadzka: mfzawadz@cyfronet.krakow.pl

\begin{tabular}{llll}
\hline Authors' contribution & B - Data Collection & D - Data Interpretation & F - Literature Search \\
A - Study Design & C - Statistical Analysis & E - Manuscript Preparation & G - Funds Collection
\end{tabular}

